\title{
Author's Copy:
}

This is a so-called personal version (author's manuscript as accepted for publishing after the review process but prior to final layout and copyediting) of the article.

'You, them, us, we, too? ... online-offline, individual-collective, forgotten- remembered, harassment-violence'

Jeff Hearn

European Journal of Women's Studies, Vol. 25(2), 2018, pp. 228-235.

ISSN: $1350-5068$

eISSN: $1461-7420$

http://journals.sagepub.com/home/ejw 
You, them, us, we, too? ... online-offline, individual-collective, forgotten- remembered, harassment-violence

\author{
Jeff Hearn ${ }^{1}$
}

\#MeToo was originally a campaign launched in 2007 by Tarana Burke, a US Black woman, against lack of services for Black women victims/survivors of abuse, especially sexual assault, in underprivileged communities. It offered support to others, framed as 'empowerment through empathy', when statutory and other support did not exist. Burke told Ebony magazine: "It wasn't built to be a viral campaign or a hashtag that is here today and forgotten tomorrow ... It was a catchphrase to be used from survivor to survivor to let folks know that they were not alone and that a movement for radical healing was happening and possible."

In October 2017, following increasing allegations, the US actor, activist, producer and singer, Alyssa Milano, initiated a new viral \#MeToo campaign. She aimed to develop support for women who had experienced abuse: to show solidarity with those who come forward and those who, for a variety of reasons, do not feel able to come forward, and so show the extent of such abuse.

Here, I have been asked to comment on: "Bearing in mind your own work, do you think that \#metoo is 'useful': in terms of triggering systemic change? In terms of its impact? In terms of bringing women together across borders?" In many ways, it is easy to answer these questions: yes, yes, and yes. Indeed, personal testimonies are an established method in feminist and other consciousness-raising movements. But to say a little more, I comment here on what appears distinctive, and in some ways new, about \#MeToo. These distinctive appearances are important in considering the questions posed.

\title{
Cyberpolitics, online-offline
}

First, \#MeToo is an example of contemporary virtual politics or cyberpolitics of sexuality and violence, made and facilitated through internet and other socio-technological relations and affordances. It builds on many interactive projects, such as the UK 'Everyday Sexism' operative since 2012 (Bates, 2014) or the Swedish \#prataomdet [\#talkaboutit], following sexual allegations against Julian Assange, and leading onto vivid discussion of policy and practice on sexual consent (Strid, 2015). A significant aspect of such virtual politics is that they seem to have both a (younger) generational profile as well as working across generations. The very technology that may be used to harass, bully and violate, to undermine gender/sexual citizenship, can be used to enhance that citizenship (Hearn, 2006).

This is not to isolate the online and the offline; the initial campaigns have spawned a whole range of other campaigns, and also policy initiatives, and strong examples of immediate

${ }^{1}$ Jeff Hearn is Professor of Sociology, University of Huddersfield, UK; Senior Professor, Gender Studies, Örebro University, Sweden; Professor Emeritus, Hanken School of Economics, Finland; and Professor Extraordinarius, University of South Africa. His latest book is Revenge Pornography; Gender, Sexualities and Motivations, with Matthew Hall, Routledge. 
collective awareness and action. To use some immediate examples: two universities where I work - Örebro University, Sweden, and Hanken School of Economics, Finland - have just in the last few days produced new, if very different, policy statements from the top down: the first using the frame of 'power language', the latter highlighting zero tolerance.

There is now a significant amount of research and informed (online) commentary on whether and how tweeting and online campaigns more generally bring social change. Such interventions appear to have been influential, at least at the margins, in high profile electoral campaigns, and also in some single issue campaigns, such as around specific law reform and consumer actions. Virtual politics can be a means to rapid, transnational spreading of ideas, information and interventions. With \#MeToo, this has been amply illustrated. In Finland, the movement caught on rather slowly, with initial responses in schools and defence forces, but now in late November is taking off; in neighboring Sweden, where it grew fast, with 70,000 women signing by late November 2017 (https://www.dn.se/nyheter/sverige/darfor-blev-metoo-uppropen-sa-starka-isverige/), there is talk of a 'social revolution'. Twitter reports that more than 1.7 million women and men have used the hashtag in 85 countries.

\section{Celebrities and workplaces}

Second, \#MeToo seems, initially at least, to have been driven by reactions and responses to high profile individual cases of what has been often characterized as sexual harassment, confirmed or alleged, by specific individual men in the public eye. In particular, it appears to have been prompted by revelations about and against men celebrities, made sometimes by women celebrities, sometimes by less well-known women. Thus, the hashtag can partly be seen as an offshoot of media and popular interest in celebrity culture, even whilst the initial focus on revelations of sexual harassment and assault from the 'entertainment' industry has broadened to other male-dominated sectors, notably politics and professions.

Perhaps significantly, at times the \#MeToo campaign has become almost synonymous with Harvey Weinstein. Maybe this intensification followed on from his hypocrisy after his previous public support for progressive causes. The campaign took off fast and with much wider impact than there was following the cases of, for example, Bill Cosby or Jimmy Savile (so vile), with the first being a Black US comedy actor, the second a White British disc jockey and television 'personality', and also dead. The viral \#MeToo campaign could be seen as part of an accumulation of reaction against celebrity cases. Seen in the UK context, it seems in some ways a follow-up to major allegations against a plethora of "show business" (a term now with new meanings) sexual abuse cases of children, young people and women by leading British men made public over recent years. Seen in the US context it might partly a delayed, cumulative reaction to and anger against Trump's boasting of "grabbing pussy".

Many of the initial reports in \#MeToo were derived from male-dominated industries, with the focus on male actors, directors, producers, parliamentarians, lawyers, journalists, academics, and the like, even technologists. More privileged gendered class, status, high visibility and occupational sectors figured strongly. Studies of women entering male-dominated sectors have long reported more harassment, perhaps part of the policing of occupational boundaries by men, whilst women in more stereotypical female jobs have sometimes under-reported, perhaps because of different gendered-sexual expectations in such jobs (e.g. Gutek and Morasch, 1982). 
More directly, gender-sexual power, sexualities and sexual abuse have often gone together (Hearn and Parkin, 1987/1995). In the case of (UK) Parliament:

"Young staff members who surround British lawmakers have no independent personnel body to appeal to if they have complaints. Instead, they are told to inform party whips, inhouse disciplinarians who were widely believed to stockpile compromising information for their own purposes. Newspapers, for their part, have often sat on reports of abuse rather than risk libel claims." (Barry, 2017)

Having, said that, the \#MeToo campaign is now spreading more widely to non-white collar and working class sectors, such as the construction industry.

Another key aspect to workplace contexts concerns protection given to certain high status, high performing employees, even if the benefit to an employer of retaining a very productive but "toxic" employee, such as a sexual harasser, may be far outweighed by the cost of keeping them (Housman and Minor, 2015). Indeed, such employees tend to drive out other employees. However, with new technologies, the 'superstar economy', whereby the successful can leverage much more, may mean "the rest of the economy is becoming more like Hollywood, where a small group of stars have long reaped a huge portion of the rewards. That means more bosses and boards may soon face decisions about whether to stand up to harassers or to overlook their behavior." (Scheiber, 2017). Change in harassment and abuse in organizations and workplaces depends on fundamental change in hierarchical, gendered, aged, classed, ethnicized and racialized workplaces.

\section{Individuals and collectivities}

Third, there are a number of individualisms in play in the expansion of the campaign, against celebrities, in allegations, responses, reactions, experiences, in the listing of individual incidents. By and large, it is individuals, rather than groups, collectives or organizations, who initially at least have tweeted or have been or are active in some other way online, whether in their own reported abuse or supporting those abused. This is exemplified in the "me" of "metoo". The highlighting of the "me" can be interpreted in many different ways, ranging from embodied claiming and the claiming of bodily integrity through to the personal as political onto resonances with neoliberal individualism. It may be seen as paralleling the current "I AM" campaign against modern slavery (https://www.iamcampaign.com/) or going further back to the "I am a man" campaigns of the Black men sanitary workers in Memphis, 1968 (https://www.civilrightsmuseum.org/i-am-a-man).

However, at the same time, the "too" of "metoo" suggests there are (many) others before, and probably afterwards to be allied with. So, in this way, it links (the) one and the other(s), perhaps even structure and agency. The "too" of "metoo" may also link the mostly unknown, perhaps anonymous, individual harassed or assaulted woman with the celebrities or proto-celebrities. In keeping with reality shows and the rest, this may be a democratization, a solidarization, of (unwanted) fame. So, while the "me" or the "I" is asserted, it is also, partially, anonymized in numbers, in solidarity, a form of determined, optimistic democratization.

\section{Memory, forgetting and surprise}


Fourth, the campaign has been associated, especially from beyond the movement, with some loss of memory and some element of surprise 'these things' still happen, in the film industry, theatre, media industry, the law, even universities - as if surely there is policy to deal this kind of thing? ! The recent discussions and disclosures on sexual harassment in the film industry and other arenas seem to have surprised some people, even with claims there is little research on this. People should not be so surprised. There is a whole genre, or genres, of books on the 'Casting Couch', some fictional some factional, some factual (Halperin, 2008; Jaher, 2014; Zimmer, 2017; see: https://www.revolvy.com/main/index.php?s=Casting\%20couch\&item_type=topic).

More generally, sexual harassment is far from new; it is just that it was not always called that. There are many examples chronicled from the nineteenth century (MacKinnon, 1979; Lambertz, 1985; Bratton, 1987; Husu et al., 1995). Mary Bulzarik (1978: 25) has reported that the victims of sexual harassment in the nineteenth century were in all occupational areas:

... railway cashiers, union organizers, garment workers, whitegoods workers, home workers, doctors, dressmakers, shopgirls, laundry workers, models, office workers, cotton mill workers, cannery workers ... broom factory workers, assistant foremen [sic], stenographers and typists, soap factory workers, hop-pickers, shoe shine girls, barmaids, legal secretaries, actresses, sales demonstrators, art students, and would-be workers at employment interviews.

More to the contemporary point, research and policy development have become well, if unevenly, developed, since its naming in the 1970s. For example, 30 years ago in 1987, the Finnish Ministry of Health and Social Affairs published a survey and bibliography detailing 341 publications and no less than ten bibliographies on sexual harassment (Högbacka et al., 1987). The same year, Wendy Parkin and I published "Sex" at "Work" (Hearn and Parkin, 1987/1995), and Liz Stanley and Sue Wise published Georgie Porgie: Sexual Harassment in Everyday Life, in which they argued against the "percentage of women who have experienced sexual harassment" approach to sexual harassment, as all women have experienced it.

A few years ago saw the 'discovery' in Finland that sexual harassment actually occurs in the national parliament (Niemi, 2010). Even though there had just earlier been major harassment scandals, for example, concerning the former parliamentary Speaker, Matti Ahde (Puustinen, 2002), this seemed to take much of the mainstream media by surprise. What is it that keeps it being rediscovered? Why is it surprising? Do people have bad memories? Is it a generational quirk that the older do not tell the younger about it? Or is it that the younger assume that the problem has been resolved until they then experience it, and then maybe think it a 'one-off', an individual problem?

So, coming back to the original questions, how can loss of (individual and collective) memory be overcome? The desire of actual and potential harassers, mainly if not only men, and their allies and passive bystanders, to obscure and cover up may be inspired by simple power, shame or taken-for-grantedness. This may be accompanied, uncomfortably, by the pressure, and sometimes constrained decision, not to disclose harassment by the harassed, mainly women. Is this too risky or just not worth mentioning? Or is the mentioning and complaint followed by further blockage? Is the aftermath, even the cover-up, more traumatic than the event? The targeting of women victim/survivors, and sometimes men, may occur twice over, in the event 
and in the cover-up. Long-term political vigilance and institutional transformation are necessary; otherwise, there will be more, repeated 'surprise' rediscoveries, and online campaigns, in five or ten years' time, followed by gender business as usual.

\section{Sexual, harassment, sexual violence, violence}

Fifth, more critically, the campaign has often been framed, especially from the outside and in public media, in terms of sexual harassment, and much less in terms of the wider questions of sexual violence, sexual assault, rape and gender/sexual domination, abuse, exploitation and oppression, . Having said that, the latter are recognized in some commentaries. For example, the Facebook group \#allavi [\#allofus], started by the Swedish parliamentarian Maria Robsham, has some 30,000 members, with women posting their experiences under the explicit naming of sexual violence [sexualiserat våld], i.e. not sexual harassment (https://www.dn.se/nyheter/sverige/han-har-inga-skivor-men-sager-att-han-vill-se-mina-finabrost/), in keeping with the continuum of sexual violence (Kelly, 1988). However, many commentaries remain limited to sexual harassment.

\#Metoo brings women together across various kinds of borders, national, class, ethnic; women come to know of other women elsewhere with similar experiences to themselves. What is less clear-cut is how and whether such online movements necessarily change persistent gendered social structures. To cite a parallel: there can be online campaigns against poverty that are successful in particular moments, but inequality continues to grow globally and also intrasocietally, if not so inter-societally. Whether \#MeToo leads to lasting collective action and solidarity and fundamental change in gender/sexual power relations is a question only be answered in due course. It is possible that \#MeToo-type campaigns raise women's voices, consciousness and solidarity, in the short term, leading, or not, onto policy change, but that these are not enforced by what has been called feminist implementation (Callerstig, 2014), so that structural, unequal gender power relations of gendered violence do not change so much. It is unlikely sexual violence will decrease significantly if societies and institutions remain fundamentally and structurally gender unequal.

This perspective concerns how wider social change in one societal domain, namely violence, intersects with another domain, polity, as its context, as well as with economy and civil society (Walby, 2009). Seen thus, there would be hope for structural change since social revolutions may occur in multiple domains simultaneously, if unevenly, with potential to disrupt the hegemony of the gender regime increasing with changes in each domain. This also directs attention to the complex form and structure of (gendered) violence regimes, including anti-violence structures, as well as possible paradoxes between relatively high levels of gender equality on some measures remaining accompanied by relatively high levels of reported sexual violence. It is such societal issues that we are researching in a new Swedish Research Council project led by Sofia Strid ('Regimes of Violence: Theorising and Explaining Variations in the Production of Violence in Welfare State Regimes, project 2017-01914).

\section{Men ... an absence presence}

Sixth and finally, while \#MeToo has successfully expanded, as well as bringing criticisms for the onus being on women, and the shortcomings of one size fitting all (http://blogs.khaleejtimes.com/2017/10/19/why-i-didnt-join-the-hashtag-me-too-bandwagon/), it 
still comes down, in short, to changing men, the main perpetrators (see Global Secretariat Team, MenEngage, 2017 on \#iPledge; Ruiz-Navarro, 2017). Men need to stop, change, and not get away with it.

I started writing this when I was traveling to Frankfurt; I began glancing through the Lufhansa airline magazine, and to my slight surprise there was an interview of star of stage, screen and now scandal, Dustin Hoffman. He said:

"When I started out, a sex scandal would have meant the end of any career. Today, if a sex video somehow gets into the public domain, you become a star. That's extraordinary!" (Heldman, 2017: 62)

How very non-prescient of the star! If nothing else, this shows how quickly gender/sexual/violence politics can shift and change - a lesson also learnt from the protomainstreaming of white supremacist sympathies by \#45. \#MeToo may usher a different gender revolution.

\section{Acknowledgements}

I am grateful to Liisa Husu and Sofia Strid for information and comments on earlier drafts.

\section{References}

Barry, Ellen (2017) 'In U.K.'s Clubby Parliament, Abuse Complaints May Be Used as Weapons', New York Times, 7 November https://www.nytimes.com/2017/11/07/world/europe/uk-parliament-misconduct.html

Bates, Laura (2014) Everyday Sexism. London: Simon \& Schuster.

Bratton, Eleanor K. (1987) 'The eye of the beholder: An interdisciplinary examination of law and social research on sexual harassment', New Mexico Law Review, 17(Winter): 91-114.

Bulzarik, Mary (1978) 'Sexual harassment at the workplace: Historical notes', Radical America, 12(4): 25-43.

Callerstig, Anne-Charlott (2014) Making Equality Work: Conflict, Ambiguities and Change Actors in the Implementation of Equality Policies in Public Sector Organisations. Doctoral thesis. Linköping: Linköping University Electronic Press.

Global Secretariat Team, MenEngage (2017) MeToo - Hear, Believe and Act: Time to be responsible, boys and men! http://menengage.org/news/hear-believe-and-act/

Gutek, Barbara and Morasch, Bruce (1982) 'Sex ratios, sex-role spillover, and sexual harassment of women at work', Journal of Social Issues, 38(4): 55-74.

Halperin, Ian (2008) Hollywood Undercover: Revealing the Sordid Secrets of Tinseltown. Edinburgh: Mainstream.

Hearn, Jeff (2006) 'The implications of information and communication technologies for sexualities and sexualised violences: contradictions of sexual citizenships', Political Geography, 25(8): 944-963. 
Hearn, Jeff and Parkin, Wendy (1987/1995) 'Sex' at 'Work': the Power and Paradox of Organization Sexuality. Hemel Hempstead: Prentice Hall/Harvester Wheatsheaf; New York; St. Martin's.

Hearn, Jeff, Strid, Sofia, Husu, Liisa and Verloo, Mieke (2016) 'Interrogating violence against women and state violence policy: gendered intersectionalities and the quality of policy in the Netherlands, Sweden, and the UK', Current Sociology, 64(4): 551-567.

Heldman, Patrick (2017) "Erfolg ist manchmal ein Unfall” ["Success is sometimes an accident"], Lufthansa magazin, 11/17: 58-62.

Husu, Liisa, Katainen, Elina, Peltonen, Eeva, Purra, Pia, Raevaara, Eeva and Tiukka, Liisa et al. (eds.) Lukukirja Suomen naisille. Helsinki: Gaudeamus.

Högbacka, Riitta, Kandolin, Irja, Haavio-Mannila, Elina and Kauppinen-Toropainen, Kaisa (1987) Sexual Harassment. Helsinki: Ministry of Social Affairs and Health. Equality Publications. Series E: Abstracts 1/1987.

Jaher, Diana Beth (2014) 'Painting with faces': The casting director in American theatre, cinema, and television. Doctoral thesis, Champaign, ILL: University of Illinois at Urbana.

Kelly, Liz (1988) Surviving Sexual Violence. London: Wiley.

Lambertz, Jan (1985) 'Sexual harassment in the nineteenth century English cotton industry', History Workshop, 19(Spring): 29-61.

MacKinnon, Catharine (1979) The Sexual Harassment of Working Women. New Haven: Yale University Press.

Niemi, Hertta (2010) Managing in the "Golden Cage” An Ethnographic Study of Work, Management and Gender in Parliamentary Administration. Doctoral thesis. Helsinki: Hanken School of Economics.

Puustinen, Liina (2002) 'Tapaus Ahde "mediatuomioistuimessa", Journalismikritiikin vuosikirja, 25(1): 56-63.

Ruiz-Navarro, Catalina (2017) Machos en rehabilitación', El Espectator 18 October. https://www.elespectador.com/opinion/machos-en-rehabilitacion-columna-718698; also 'The ugly truths of men are not said out loud: that is the pact of patriarchy', October 29, http://www.kractivist.org/the-ugly-truths-of-men-are-not-said-out-loud-that-is-the-pact-ofpatriarchy-metoo/ 
Scheiber, Noam (2017) 'In a superstar economy, a bull market in superstar harassers', New York Times, 31 October. https://www.nytimes.com/2017/10/31/business/superstars-sexualharassment.html

Stanley, Liz and Wise, Sue (1987) Georgie Porgie: Sexual Harassment in Everyday Life. London: Pandora.

Strid, Sofia (2015) “\#talkaboutit: talking about consent and coercion”, Sylvia Walby et al. Stopping Rape. Bristol: Policy Press.

Walby, Sylvia (2009) Globalization and Inequalities: Complexity and Contested Modernities. London: Sage.

Zimmer, Ben (2017) 'Casting Couch': The origins of a pernicious Hollywood cliché, The Atlantic, 17 October. https://www.theatlantic.com/entertainment/archive/2017/10/casting-couchthe-origins-of-a-pernicious-hollywood-cliche/543000/ 